\title{
Children's Problem in Kindergarten and Services Treated by Teacher (Studies in Kindergarten Dharmawanita UNP)
}

\author{
Rivda Yetti \\ Department of Early Chidlhood Education \\ Faculty of Education \\ Universitas Negeri Padang \\ Padang, Indonesia \\ labor.pgpaudunp@gmail.com
}

\begin{abstract}
The research is based on the findings of children problem found in Dharmawanita Laboratorium Kindergarten. Therefore it is necessary to identify and describe the problems faced by the child and how the services can be provided by the teacher. The purpose of this study is to describe the problems that occur in children in kindergarten and know the services provided by teachers in solving the child's problem. The research was conducted with qualitative approach. Data were collected by observation, interview, and documentation techniques. The data obtained were analyzed by Miles and Huberman method. The findings of this study revealed that the problems experienced by children in kindergarten are: hit, thumb sucking, disturbing and lazy to move. From this research is expected teacher can develop form high touch service and high tech to children.
\end{abstract}

Keywords --children's problem; teacher; service

\section{INTRODUCTION}

School is an educational institution in which there is a relationship between educators and students. The relationship must exist at every level and educational unit, from the kindergarten level to the level of Higher Educatio. The students are meant here are children in the kindergarten education unit. The relationship between educators and students can not be done randomly, meaning the relationship of educators with students can not be done in vain. The relationship should be done well and correctly, when, where, under any circumstances and in any way that it becomes a better educator relationship with the child.

Education in educational unit Kindergarten, followed by children aged between 4-6 years. The child at this age is called the golden age, because the child's developmental opportunities are very valuable. Hurlock [1] argues that the golden period occurred because of the considerable opportunity for the formation and development of the potential of the child, where the child is currently experiencing a considerable development both physically, psychologically, and socially.

Hurlock [1] asserted that in kindergarten age, the child is in development so susceptible to trouble, so children in this age are often also called difficult age or preschool age who are still very happy with exploring, asking, imitating, and creative. It is understandable that the developments that occur in kindergarten children need services to overcome the problems that occur in the child. If the problems are not addressed properly and correctly will affect the development of children and can hamper further development.

In the educational process, the relationship between educators and students, especially in kindergarten must be able to guarantee the certainty of the growth of the educational situation. If it can not create a good relationship between the educator and the kindergarten children, it will lead to a situation that is contrary to the meaning and purpose of education itself, such as: harassment, humiliation, competition, hostility, and so forth. The relationship between educators and kindergarten children is a land for the development of good educational situation and includes children's problems in it.

In line with the research conducted by Hizmawaty [2] The results of his research is the factors that affect the most dominant child aggressiveness are internal factors such as adaptability and socializing, while external factors imitation or imitation process. Overcoming the problem on the child what the teacher does is to advise the child with a more intense talking with an approach (talk while looking at the face) and give praise to the child.

The next opinion was made by Saomah [3] about "Children's Problems and Handling Efforts". According to the factors causing problems in children are: 1) innate, the child with all circumstances that exist in him, 2) family environment includes parental care, social circumstances, and the family economy, 3) the school environment, teachers, teaching and learning process, aids, and curriculum as well as 4) society includes association, norm, and custom.

Based on the phenomenon from the initial observations of researchers in the field, still found children who have problems in Dharmawanita Laboratory Kindergarten School, among others: children behave and anti-social attacks, children annoying their friends, lazy children, children still have dependence such as: / thumbs up and visible children not participating in social.

The problems that exist in the kindergarten children if left to drag on will bring children into troubled children and resulted in inhibition of child development from the ideal development phase. While the child at middle age 
kindergarten experienced a rapid development of physical and mental. Therefore it is necessary to identify and describe the problems faced by the child and how the services provided by the teacher.

Based on the above phenomenon, researchers are interested to investigate in depth and describe about the problems of children and the service of teacherr for children in Dharmawanita Laboratory Kindergarten School.

The phase of early age is a moment that is very important for the development of children. Recent research shows the child's brain is experiencing a very rapid development. Early age is also often referred to as the golden age. Golden age is a period in which all the stimulation of all aspects of development take an important role for the growth of the next child.

According to Fadlillah [4] early childhood is a child who ranged between 0-6 years of age who have growth and extraordinary developments that bring a variety of uniqueness on him. Further according to Sujiono [5] early childhood is a person who is experiencing a process of rapid development and fundamental to the next life. Further added by Mulyasa [6], that early childhood is an individual who is experiencing the process of growth and development is very rapid, even said to be a leap of development. According to Willis [7] in learning, preschoolers / early childhood have tried and wrong nature (trial and error), experimenting with objects, doing something themselves based on curiosity, children learning because they are ready to learn, learning gradually, ready to learn at the time and different occasions Froebel [8] states that children are naturally capable of thinking, acting and growing by expressing their own interests, interests, and powers.

According to a psychological view, early childhood has different characteristics than the children above 8 years. Early childhood is very creative, has a very big curiosity The characteristics can be seen from the physical, social, emotional, and cognitive aspects, for that in early childhood is needed direction and guidance regarding the characteristics above, in order for a balanced child's development between physical, cognitive, socio-emotional, creativity, and language to form a whole person. According to Triyon and Lilientha [9], developmental tasks that children of kindergarten age must live in are :

1. Evolving into an independent person. At this time, children learn to become independent and responsible person with his actions. For example in kindergarten, after the children do activities such as coloring programs then the child is encouraged to clean up the tools of coloring.

2. Learn to give, share, and gain affection. The ability to give each other and receive mutual love between one child with another or from educators. This is a provision for children to face more complex communities in elementary schools and communities later.

3. Learn to mingle, that is, develop communication skills and interact with peers, and learn to deal with various problems gained from the results of these interactions.

4. Learn to control theirself. Children learn to hold back and behave according to expectations or rules around them.
From here the child begins to understand a consequence or effect of a behavior.

5. Learn the various roles in society. Children learn to understand there are various roles in this life that have their own duties and responsibilities.

6. Learn to know the body of each.

7. Develop fine and coarse motor skills, i.e children learn to co-ordinate smooth muscles to perform drawing, folding, coloring, cutting, forming points as well as developing coarse muscle coordination such as running, jumping, catching the ball, and kicking.

8. Learn to recognize the physical environment, by comparing it from either size, color, shape. This is meant the child can use appropriately.

9. Learn to master a new vocabulary to understand something.

10. Develop positive feelings with affection for the environment around them. Both with kindergarten educators, peers, and with animals, and plants.

Furthermore, Hurlock [1] suggests that childhood developmental tasks are the result of physical maturity (learning to walk), others are mainly developed from cultural pressures, societies, learning to read, play, or learn to play the role of gender, but still exist others arising from personal values, aspirations, and individuals (choosing and preparing for a job). This period is a sensitive period, children begin to be sensitive to accept various efforts to develop the full potential of children. Therefore, needed conditions and stimulation in accordance with the needs of children for the development is achieved optimally. In learning in kindergarten children are expected not only ready to enter the basic education level, but more important for children get physicalmotor, intellectual, social, and emotional stimulation in accordance with the age level.

\section{METHODOLOGY}

The approach used in this study is a qualitative approach, which is trying to reveal the implementation of services by teachers to the problems of children in DharmawanitaLaboratory Kindergarten School. According to Yusuf [10] qualitative research is seeking meaning, understanding about a phenomenon, event, and human life by engaging directly and / or indirectly in the settings studied, contextual, and thorough.

This research uses observation, interview, and documentation techniques to collect the required information. This is in line with Sugiyono [12] who argued that in qualitative research the data collection is done on natural setting, primary data source, and data collection techniques more on participant observation, in depth interview, and documentation. 


\section{RESULT}

Based on the findings of research and discussion, can be found some conclusions as follows: Children's problems found are: hit, thumb sucking, disturbing and lazy to move.

While the factors causing Child problems are as follows:

1. Beating is caused by factors outside the child's self that triggers aggressiveness to hit, among others: the foot stepped on, shoulders hit, etc. Sucking the thumb is caused by a habit factor from within the child.

2. Disturbing caused by behavioral factors from within the child is teasing to make friends not calm.

3. Lazy move caused by factors from within the child is the child's reluctance to perform physical movements that should / should he done.

Form of Service of kindergarten teachers Dharmawanita UNP in addressing the problems of kindergarten children in accordance with the concept of solving problems faced by children. The forms of teacher services are as follows:

1. The teacher's service to the child's beating behavior by: giving understanding, advising and asking the children to forgive one another.

2. Teacher service to child's thumb sucking behavior by: giving understanding, lowering children's hands, advising, multiplying drawing activity.

3. The teacher's service to the child's disturbing behavior by: embracing, advising, telling stories, giving understanding and asking the children to forgive one another.

4. The teacher's service to the lazy behavior of moving children by: advising, giving understanding, giving examples, and inviting children to play motion together.

\section{CONCLUSION}

Based on the research and conclusions above the services provided by teachers to address the problems of kindergarten children should be done with a variety of approaches consisting of three forms of approaches are:

1. Instructional and interactive approach

Instructional and interactive approach, which is integrated with the implementation of learning activities programs. For example create atmosphere and class activities are fun and varied.

2. Approach with the system

Approach with system, that is by giving atmosphere of school and environment that support child development.

3. Personal development approach

Personal development approach, which provides opportunities for children to develop in accordance with the conditions and ability himself.

\section{References}

[1] Hurlock, Elizabeth B dan Dhama, Agus (eds). Perkembangan Anak Jilid 1 edisi ke-6. Alih Bahasa: Meitasari Tjandrasa dan Muslichah Zarkasih. Jakarta: Erlangga. 2005
[2] Hizmawaty, D. MZ.Faktor Penyebab Agresivitas Anak Usia 5-6 Tahun Di TK Mekarsari Jungkat. Artikel Penelitian. Universitas Tangjungpura: Pontianak.2013

[3] Saomah, Aas.Permasalahan - permasalahan Anak dan Upaya Penanganannya. Makalah, Disajikan pada Pendidikan dan Pelatihan Strategi Peningkatan Penanganan Kesulitan Belajar Anak Taman Kanakkanak bagi Para Guru TK di Kelurahan Melong, Cimahi.Universitas Pendidikan Indonesia.2004

[4] Fadlillah, Muhammad. Desain Pembelajaran PAUD. Jogjakarta: Ar-Ruzz Media. 2012

[5] Sujiono, Yuliani Nurani. Konsep Dasar Pendidikan Anak Usia Dini.2011

[6] Mulyasa.Manajemen PAUD. Bandung: PT Remaja Rosdakarya.2012

[7] Willis, J.S.The Prevalence of Behavior Symptoms in Younger Elementary School Children. American. Orthopsychiatry.2012

[8] Smith, Samuel. Ideas of The Great Educators. New York: Barners \& Noble Books. 1979

[9] Izzaty, Rita Eka. Mengenali Permasalahan Perkembangan Anak Usia TK. Jakarta: Depdiknas Dirjen Pembinaan Pendidikan Tenaga Kependidikan dan Ketenagaan Perguruan Tinggi Jakarta: Indeks.2005

[10] Yusuf, A. Muri. Metodologi Penelitian. Padang: UNP Press.2014

[11] Sugiyono. Metode Penelitian Kuantitatif Kualitatif dan R\&D. Bandung: Alfabeta.2009 